\title{
A History of Fire Testing
}

J. Randall Lawson

QC

100

.45753

\#/628

2009

c. 2
NLT

National Instifute of Standards and Technology

U.S. Department of Commerce 


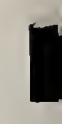

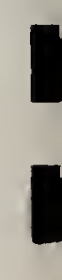

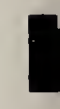

I

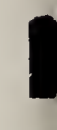

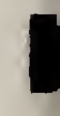

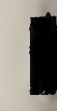

I

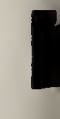

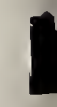

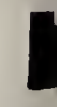

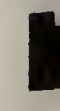

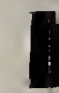

, 


\section{NIST Technical Note 1628}

\section{A History of Fire Testing}

J. Randall Lawson

U.S. Department of Commerce

Building and Fire Research Laboratory National Institute of Standards and Technology Gaithersburg, MD 20899-8661

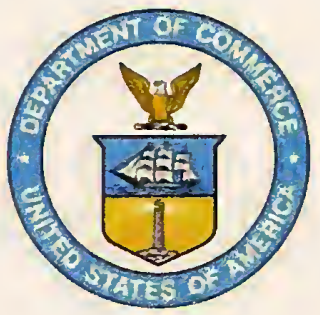

U.S. Department of Commerce

Gary Locke, Secretary

National Institute of Standards and Technology Patrick D. Gallagher, Acting Director 



\section{CONTENTS}

List of Figures $\ldots \ldots \ldots \ldots \ldots \ldots \ldots \ldots \ldots \ldots \ldots \ldots \ldots \ldots \ldots \ldots \ldots \ldots \ldots$

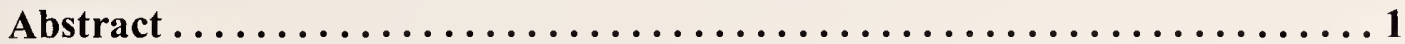

INTRODUCTION $\ldots \ldots \ldots \ldots \ldots \ldots \ldots \ldots \ldots \ldots \ldots \ldots \ldots \ldots$

The First Study of Fire $\ldots \ldots \ldots \ldots \ldots \ldots \ldots \ldots \ldots \ldots \ldots \ldots \ldots$

Mathematical Foundations of Fire Testing $\ldots \ldots \ldots \ldots \ldots \ldots \ldots \ldots 4$

Fire Testing and Revolutions in Timekeeping. $\ldots \ldots \ldots \ldots \ldots \ldots \ldots \ldots$

Scientific Foundations of Fire Testing $\ldots \ldots \ldots \ldots \ldots \ldots \ldots \ldots \ldots$

First Revolution in Fire Testing - Measurement Tools and Necessity .... . 10

Second Revolution in Fire Testing - Data Recording Machines/Knowledge

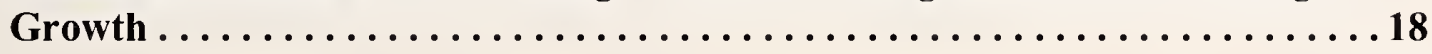

Third Revolution in Fire Testing - Computer Data Collection/Analysis

Tools ...........................................

New Opportunities - Short Term Needs in Fire Testing $\ldots \ldots \ldots \ldots \ldots 34$

A Look into the Distant Future of Fire Testing .................. 39

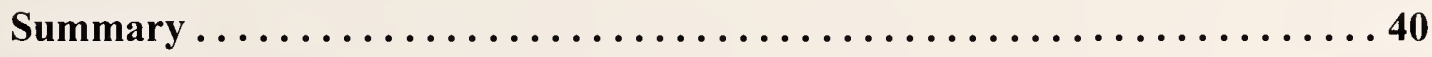

Acknowledgements .................................41 


\section{LIST OF FIGURES}

Figure 1 Galileo thermoscope sketch (left) photograph of modern

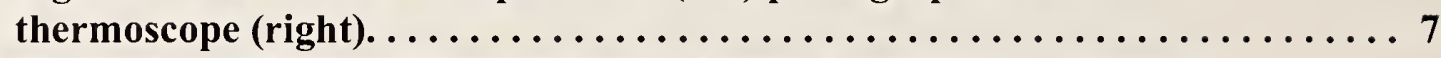
Figure 2 NBS Federal Triangle fire test (left) \& NBS column furnace

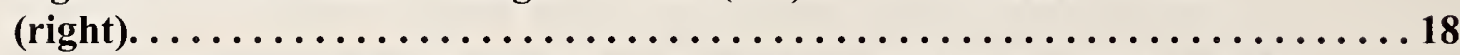
Figure 3 Photograph of Tunnel Test Apparatus, ASTM E84, NFPA 255,

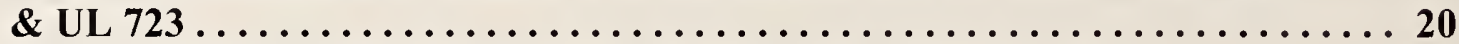
Figure 4 NBS Smoke Chamber (left) \& Sketch of Toxicity Test Chamber (right).................................... 26 Figure 5 Photograph of strip chart recorders (left) and computer terminal

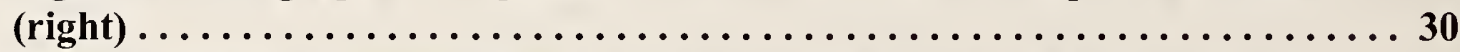
Figure 6 First $\mathrm{O}_{2}$ Consumption Calorimeters, Furniture Calorimeter (left) \& Cone Calorimeter (right). . . . . . . . . . . . . . . . . . . . . . 32 


\title{
A History of Fire Testing
}

By

\author{
James Randall Lawson
}

\begin{abstract}
This paper discusses the breakthroughs in science and engineering that have brought fire testing technology to its current state of maturity and provides insight into the possibilities for future fire test development by highlighting some areas where advancements are needed. The quest for understanding the properties of fire has been a part of the human experience since the first primitive human viewed the glow of a flame potentially 2.5 million years ago, during the Paleolithic Period. Since these early observations, humankind slowly developed the knowledge to use and understand fire. However, the initial revolution in fire testing did not begin until recently, in the nineteenth century, when the basic tools were developed that allowed for remote measurement of temperatures and heat flow. Discoveries such as the "thermoelectric effect" and the development of the First Law of Thermodynamics led to the creation of tools for calorimetry providing for the measurement of temperatures and heat flux. The second revolution in measuring and understanding fire occurred in the early twentieth century with worldwide recognition that scientifically based fire standards were needed to protect life and property. At the same time engineering innovation developed electromechanical equipment that could automatically record data measured from fire experiments. This advancement in data recording allowed for the detailed study of measured fire behavior. The third revolution in fire testing (measurement technology) occurred in the last half of the twentieth century with the development of affordable digital data logging equipment and computers that enhanced data analysis and the development of scientifically based predictive models. Wide spread use of technology and computational methods have opened the theoretical world which provides insight into the subtle features of fire dynamics and provides a means for developing a greater understanding of fire test method performance. Fire measurement technology now has the scientific and computational tools to make significant advancements in the development of fire safety standards. Use of these tools has directed attention to improvements needed in testing for structural fire endurance to enhance fire resistant structural designs. This would include, but not be limited to, advancements in testing of structural components, assemblies, and systems under realistic simulations of fire and load conditions. The objective for these new tests would be to enhance structural performance so that uncontrolled building fires result in burnout without partial or total collapse. Additionally, these fire measurement technologies would also lead to improvements in ignition resistant materials, surface flammability, fire growth, smoke and toxic gas production that will save lives and reduce the high cost of unwanted fires.
\end{abstract}

Key Words: engineering, fire, fire science, fire tests, history, measurement, science 


\section{Introduction}

Basic breakthroughs in science, engineering, and measurement technology have brought fire testing to its current state of maturity. It has been a long and slow process that has seen several significant periods of growth. This growth in fire knowledge is associated with developments from a small number of scientists and engineers. The complete understanding of fire and its behavior in the wide range of environments awaits discovery and will be accomplished by future generations. Currently, there is still much to be learned about fire and much yet to be done with the development of and application of fire test methods. This treatise provides a history of the science that supports present work, the development of tools that make the study of fire possible, and the development of fire test methods that reflect the state of present day technology. The work is not meant to be a complete and comprehensive dissertation on the development of fire test methods but is an attempt to highlight significant contributions that have influenced the development of fire testing, in North America. Additionally, this paper provides insight into new opportunities for future studies and into the possibilities for development of future fire test methods.

\section{The First Study of Fire}

The quest for understanding the properties of fire has been a part of our experience since the first primitive human viewed the glow of a flame potentially 2.5 million years ago, during the Paleolithic Period. Since these early observations, humankind slowly developed the knowledge to use and understand fire. This early period of learning about fire took place during a time before written records were established; therefore, further 
meaningful discussion only allows it to be addressed hypothetically. However, a simple model may be applied to understanding the learning experience early human's had with fire. This simplistic model involves remembering how we as individuals learned about fire as we grew from infancy. We likely first saw a fire at a very early age. It may have been in the wilderness, which would have been the case of early humans. But, in our period of what we call modern times, it was likely a fire inside our homes, a stove, a fire place, or the first candle on our birthday cake. We were intrigued by the glow, the subtle wavering of the flame, and the flame's soft transparent image. We wanted to put our finger in it, touch it, and feel what it was like, and if we were not watched over carefully by an older knowledgeable human, we would conduct our first fire test. Within a split second our first fire test would have achieved results, as we squealed with pain. But, our very first fire test was successfully completed, and we learned that fire was what we call hot and can seriously injure a human. With this experiment we also discovered heat, but we did not understand it. The first fires that early humans saw were likely created by nature, areas ignited by lightning or if they lived in a volcanic region, fires ignited by lava. As with the curious child, these early humans wanted to know more about fire. They may have also observed that fires could be extinguished by rainfall (the first discovery of sprinklers) or stopped by flowing streams. Also, early in the process these humans likely learned how to move fire from one location to another without being burned. With this knowledge, humankind has now developed the concept of using fires, and they understood that there were unwanted fires that may destroy them or fires that they could bring home to help warm their shelter. Even though they did not understand that air contained oxygen needed for combustion, they had developed the knowledge that 
heat combined with fuel would produce a fire. They understood two sides of the basic fire triangle. This knowledge led to humans actually being able to produce fires as they needed them and established the basis for working with fire that has continued for thousands of years. This primitive physical science knowledge of heat and fire combined with a growing knowledge of mathematics set the stage for the revolutions that led to the development of fire tests. It is clear that humans were not only using fire for domestic purposes during early written history but they were clearly conducting fire tests to develop weapons systems. It has been learned that "Greek Fire" was used in warfare during the seventh century, and the Chinese developed and used flame-throwers in the tenth century. ${ }^{1,2}$ This document will not address fire tests as they may have been applied to the development of military weapons; it will focus on the history of the development of fire tests used to provide protection for humans and property.

\section{Mathematical Foundations of Fire Testing}

Before addressing the specifics associated with fire testing, it is appropriate to briefly highlight the advancements in mathematics that have made fire testing possible. The development of the Arabic numbers system, arithmetic, algebra, geometry, trigonometry, and the calculus provided the most basic tools for studying fire. These mathematical tools, as they were developed, have been applied throughout the centuries to the study of fire behavior. The growth of statistical methods provide the basic methodologies for analyzing fire research results and fire test data, allowing for fire test methods to be fine tuned so that they produce meaningful and repeatable results. Additionally, statistical

\footnotetext{
${ }^{1}$ Partington, J.R.. "A History of Greek Fire and Gunpowder," Heffer, 1960

2 ChinaCulture.org, "The flame-thrower." September 2008
} 
methods provide tools that assist in predicting fire behavior. The scientific efforts which bring us to our period in fire science could not have been accomplished without the application of supporting mathematics.

\section{Fire Testing and Revolutions in Timekeeping}

As one attempts to understand fire and fire testing it becomes clear that nearly all facets of the science are time related. Without a good understanding of time and the ability to measure time accurately advancements in fire testing would be limited. Nearly all fire tests have time as a measurement parameter and many test results are reported in units of time relative to the test method. The concept of time has been important from the beginning of the human experience. Thousands of years ago humans in Africa, Asia, and Eastern Europe developed elementary means to measure time using sundials, and as time passed rudimentary water clocks were developed, and then came water/mechanical clocks. ${ }^{3}$ This eventually led to increased accuracy with a major breakthrough in time keeping when Englishman John Harrison, “won the British government's 1714 prize (worth more than $\$ 10,000,000$ in today's currency)." His invention was a mechanical clock with an error of only one-fifth of a second per day. ${ }^{3}$ In the 1920 s, timekeeping received even greater accuracy with the development of electronic, quartz crystal clocks. ${ }^{3}$ These types of clocks are commonly found throughout current day fire test laboratories. Modern clocks, either mechanical or electronic, represent an indispensable tool that is necessary for modern fire testing.

\footnotetext{
${ }^{3}$ National Institute of Standard and Technology, "A Walk through Time, Early Clocks," http://physics.nist.gov/GenInt/Time/early./hutunl, May 2008.
} 


\section{Scientific Foundations of Fire Testing}

Science and technology that provided the foundations for fire testing were developed during a period from the $16^{\text {th }}$ Century through the $18^{\text {th }}$ Century.

\section{Combustion Processes - What is a flame?}

One of the first detailed efforts that became widely published relative to describing the burning process occurred in about 1825 with a series of children's lectures by Michael Faraday at the "Royal Institution of Great Britain." He produced at least six lectures that made up the series entitled, "Chemical History of a Candle." These Royal Institution lectures during the 1820 s provide insight into what was known about combustion and fire, at the time. ${ }^{4}$ In 1885 , Mallard and Le Chatelier published their work providing more detailed analysis of combustion processes proposing that it is the propagation of heat back through layers of gas that is the controlling mechanism in flame propagation. ${ }^{5}$ Work created by these and other early pioneers in fire science have been followed by numerous $20^{\text {th }}$ Century researchers who further defined the combustion processes and properties of a flame that are being used in current fire test methods. ${ }^{5}$

\section{Temperature}

The great Italian astronomer "Galileo" realized that there was a need to measure heat and in 1593 developed the thermoscope. ${ }^{6,7}$ This simple device was constructed from a glass bulb with an attached glass tube fitted vertically to the center of a glass bowl containing water and exposed to the open-air. (Figure 1)

\footnotetext{
${ }^{4}$ Faraday, Michael; "Faraday's Chemical History of a Candle," originally published in 1861, Chicago Review Press, Chicago, 1988.

${ }^{5}$ Glassman, Irvin; “Combustion," Academic Press Inc., New York, 1977.

${ }^{6}$ Wolf, A., "A History of Science, Technology and Philosophy in the Sixteenth and Seventeenth Centuries," Allen and Unwin, London, UK, 1935.

${ }^{7}$ Miller, Franklin Jr.; Dillon, Thomas J.; Smith, Malcolm K., "Concepts in Physics," ${ }^{\text {rd }}$ Edition, Harcourt Brace Jovanovich, Publishers, New York, 1980.
} 

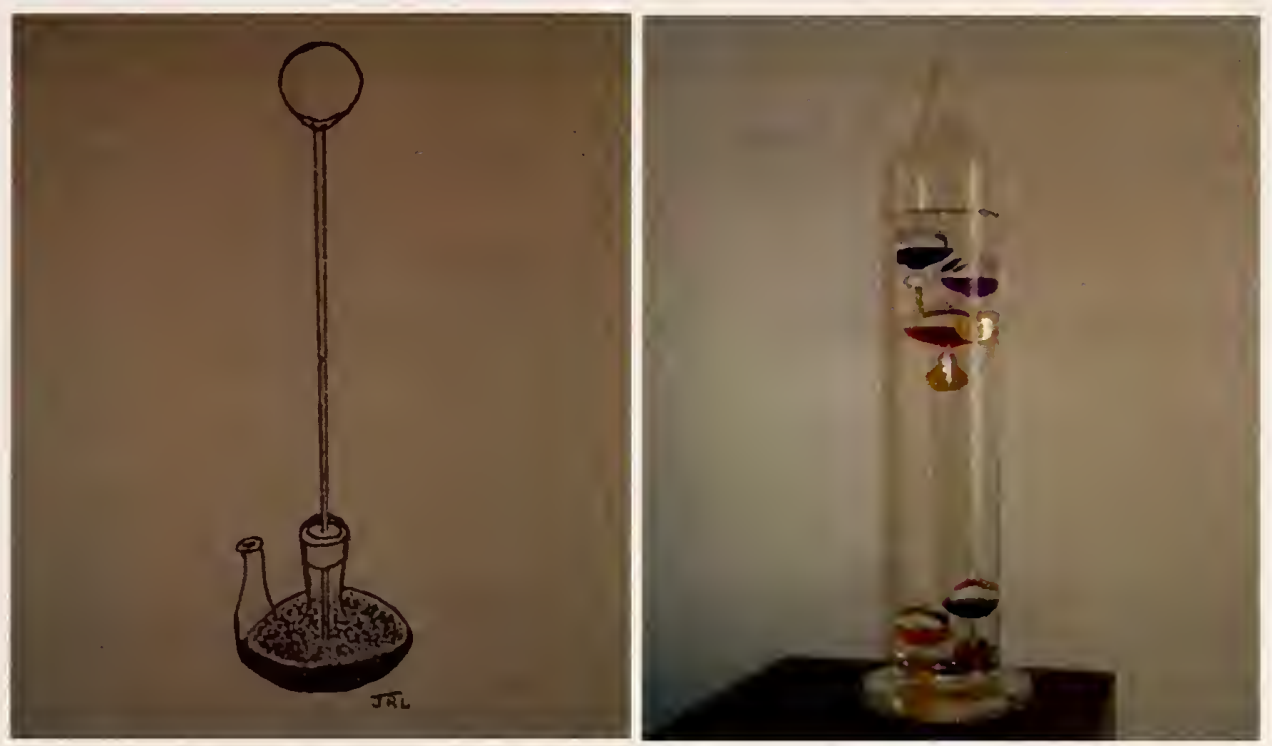

\section{Figure 1 Galileo thermoscope sketch (left) photograph of modern thermoscope}

(right).

Note: Sketches and photographs presented in this document were drawn or taken by NBS/NIST personnel.

This instrument was not practical for measuring temperatures produced by fire but provided a tool for studying the effects of temperature change. About 120 years later, in 1714, a German instrument maker Gabriel Fahrenheit invented the mercury-in-glass thermometer. ${ }^{8}$ With this instrument he also developed the Fahrenheit temperature scale. However, a temperature scale developed in 1742 by a Swedish astronomer, Anders Celsius, became the most widely used temperature scale for fire testing, originally the Centigrade scale, now the Celsius scale. ${ }^{8}$

\section{Heat and Thermodynamics}

The concept of heat was not understood well until the late 1700s. This understanding primarily resulted from the studies and writings of Count Rumford, (also known as

\footnotetext{
${ }^{8}$ Nordmann, Joseph, "What is Chemistry, A Chemical View of Nature," Harper \& Row Publishers, New York, 1974.
} 
Benjamin Thompson) born in North Woburn, Massachusetts. ${ }^{7}$ Rumford was a Tory who went to England and later became the Minister of War, in Bavaria. In 1789, Rumford presented an essay to the Royal Society of London that described how heat was associated with motion and friction. This essay was developed from observations and experiments carried out on the boring of cannon barrels. ${ }^{9}$ These findings opened the door for the understanding of heat and thermodynamics that are additional elements forming the foundation of fire testing technology.

\section{Heat Transfer through Solids}

In the 1840 s, German physician Julius Mayer published additional work on understanding heat. This work on heat and heat flow was refined further by English physicists James Joule and by German physicist Hermann von Helmholtz. ${ }^{7}$

Efforts by each of these three contributors on heat relative to the energy gained by molecules of a body when heat flows into it and that molecules of a body loses energy when heat flows out of it led to the "First Law of Thermodynamics." In 1850, German physicist Rudolf Clausius further defined heat transfer processes, which led to development of the "Second Law of Thermodynamics." 10

\section{Heat Transfer by Thermal Radiation}

During the 1600s, English Physicist Sir Isaac Newton and Dutch physicist Christiaan Huygens presented competing theories on the properties of light. Newton had published a work on his studies concerning light, entitled Optciks, and stated that light was made up of very small particles that traveled in a straight line. ${ }^{9}$ Conversely, Huygens postulated

\footnotetext{
${ }^{9}$ Ripley, J. A. Jr., "The Elements and Structure of the Physical Sciences," John Wiley \& Sons, Inc., New York, 1965.

${ }^{10}$ American Society for Testing and Materials, "Manual on the Use of Thermocouples in Temperature Measurement," ASTM STP 470A, ASTM Committee E-20 on Temperature Measurement and Subcommittee IV on Thermocouples, Philadelphia, PA,
} 
that light was a phenomenon in which it consisted of waves that traveled in a straight line. ${ }^{7}$

The issues associated with light were not resolved until the early 1900s when J. Clerk Maxwell determined that light was related to electromagnetic waves, and Max Planck explained details associated with light radiation. ${ }^{9}$ With this, the achievement in physics that is now regarded as "classical physics" was established and the electromagnetic spectrum was unified showing that light, radiant heat, X-rays, and radio waves were found to be made up of electromagnetic waves differing only in wavelength and frequency. ${ }^{9}$

Additionally, it was found that light could also exist as photons or extremely small particles as proposed by Newton. ${ }^{9}$ However, a deeper discussion of quantum theory is not necessary for this essay on fire testing. These findings when combined with heat transfer knowledge paved the way for understanding and measuring thermal radiation.

\section{Fluid Dynamics}

Finally, in the early 1700 s, the study of fluids led Daniel Bernoulli, of the Netherlands, to formulate what is known as the Bernoulli Equation. ${ }^{7}$ This work mathematically explains the hydrodynamic properties of fluids and provided a means to develop new measurement instruments that would be useful to developing fire test methods. Following Bernoulli's lead, in 1732 a Frenchman named Henri Pitot developed a device useful in measuring fluid flows. This device carries the inventor's name, the Pitot tube. ${ }^{11}$ Pitot tubes have been extensively used in fire testing, but can experience significant problems when exposed to high intensity and smoky fires.

${ }^{11}$ Streeter, Victor L., "Fluid Mechanics," 3rd Edition, McGraw-Hill Book Company, 1962. 
The above mathematical, scientific, and engineering breakthroughs provided a sound foundation for the first revolution in fire testing.

\section{First Revolution in Fire Testing - Measurement Tools and Necessity}

The understanding of temperature and heat flow discussed above established the foundation for the scientific and engineering revolution that followed. This revolution that led to modern fire testing did not begin until relatively recently, in the 19th Century, when the basic tools were developed that allowed for the measurement of temperature and heat flow. More importantly, this first revolution period also included the development of technologies that allowed for the remote measurement of temperatures and heat flow. Since attempts to measure fire carries significant risks related to life and safety it is imperative that the measurement of fire behavior be done remotely. The ability to remotely measure fire phenomena brought fire testing into this period of discovery and development. Discoveries such as the "thermoelectric effect" and thermodynamics led to the creation of tools for calorimetry, providing for the measurement of temperatures and heat flux.

In the early to mid-1800s, numerous researchers were working on processes in physics that led to the development of the thermocouple. No single person was responsible for development of the thermocouple; however, three individuals are attributed with making the appropriate scientific connections that explained the electromotive force generated by the junction of two dissimilar metals. These were Thomas Johann Seebeck, Jean Charles Peltier, and William Thomson, a.k.a., Lord Kelvin. ${ }^{12,13}$ Work by these individuals

\footnotetext{
${ }^{12}$ Considine, Douglas M., Editor, "Process Instruments and Controls Handbook, $2^{\text {nd }}$ Edition, McGraw-Hill Company, New York, 1974.

${ }^{13}$ American Society for Testing and Materials, "Manual on the Use of Thermocouples in Temperature Measurement," Special Technical Publication 470A, Philadelphia, PA, 1974.
} 
established the principles for the construction and use of thermocouples. Establishment of the thermocouple soon led to the development of other devices that would be used in fire testing. One of these devices was the copper calorimeter. As early as 1876, Maxwell was constructing and using copper calorimeters to measure heat flow during his laboratory experiments. ${ }^{14}$ Additionally, during the period between 1879 and 1884, the Stefan-Boltzmann law further defined the earlier work by Planck and established working parameters for energy flux radiated by blackbody thermal systems. ${ }^{15}$ This work on blackbody radiation was carried out by Austrian researchers Jozef Stefan and Ludwig Boltzmann. ${ }^{16}$ These two devices, the thermocouple and copper calorimeter, opened the way for making remote measurements of temperature and heat flow during fire tests. As mentioned earlier, there is a need in fire testing to remotely measure the flow of fire gases. The early work by Bernoulli and Pitot laid the groundwork for making gas flow measurements; however, the Pitot tube did not function well with certain types of fire experiments and fire tests. Another electrically operated device known as the hot-wire anemometer, described by Louis King in $1914,{ }^{17}$ was also used by some researchers for measuring low flow rates from fires. Both of these devices usually worked well until temperatures got too high or the fire produced smoke. Smoke particles can accumulate on the probe measurement wire or around and inside the Pitot tube opening, interfering with instrument operation and making the measurements useless. These issues were

\footnotetext{
${ }^{14}$ The Scientific Letters and Papers of James Clerk Maxwell, Volume III, Edited by P. M. Harman, Cambridge University, 2002.

${ }^{15}$ Rohsenow, Warren M., and Hartnett, James P., Editors, "Handbook of Heat Transfer," McGraw- Hill Book Company, New York, 1973.

${ }^{16} \mathrm{http} / /$ en.wikipedia.org/wiki/Stefen-Bollzumamn law., July 18, 2008.

${ }^{17}$ King, Louis V., "On the Convection of Heat from Small Cylinders in a Stream of Fluid: Determination of the Convection Constants of Small Platinum Wires, with Applications to Hot-Wire Anemometry,"

Philosophical transaction of the Royal Society of London. Series A: Containing paper of a mathematical or physical character, 1914.
} 
recognized by McCaffrey, of the National Bureau of Standards, and Heskestad, of Factory Mutual Research Corp., and they developed a new robust means for measuring the flow of fire gases. ${ }^{18}$ This measurement device, the "bidirectional probe" developed in the 1970s, has had a subtle but significant impact on fire testing. The "bidirectional probe" has made it possible to measure flows in both directions through doorways with one instrument, and the rugged nature of the device allows it to be used to measure very low gas flow rates or measure high gas flow rates produced by intense fires.

Additionally, the measurement device is less likely to be affected by dense smoke. The bidirectional probe coupled with modern pressure transducers and data logging systems have solved a major problem, and it allows for the accurate measurement of gas flows for a wide range of fire test conditions.

\section{Fire Test Development}

Although fire has been a point of scientific study for thousands of years the development of scientifically based fire tests for buildings and occupant protection appears to be less than 300 years old. The earliest references found for this paper related to fire safety tests showed that Obadiah Wyld had developed a fire retardant mixture for fabrics and received a British patent for it in $1735 .{ }^{19}$ It is clear that this patent could not have been obtained without using some form of fire test to quantify performance of the fire retardant mixture. Following Wyld's studies, Gay-Lussac carried out extensive studies on the fire

\footnotetext{
${ }_{18}^{18}$ McCaffrey, B., and Heskestad, G., Combustion and Flame, Vol. 26., pp. 125-127, 1976.

${ }^{19}$ Wyld, O., British Patent No. 551, 1735.
} 
resistance of fabrics used in theater curtains, and in 1821 Gay-Lussac published a list of substances found to effectively improve fire resistance. ${ }^{20}$

This thesis will now focus specifically on fire test method development in North America. In many cases, fire test methods were being development in other parts of the world, primarily in Europe and Asia. This paper will not attempt to address all of these efforts; however, it should be noted that some of the fire test development work carried out in North America reflected efforts that were also underway in other parts of the world. Furthermore, it should be noted that many fire test methods similar to the ones described in this document were also developed by non-ASTM (American Society for Testing and Materials) standards bodies, both North American and international organizations. In order to keep the history simple, attempts have been made to address the initial development of a fire test method, and to associate the test with the standards organization that initially adopted the method. The complex developmental history for some fire test methods has made it difficult to accurately present a simple history.

\section{Major Fires Identify Needs}

One of the primary driving forces in North America associated with the development of fire test methods was the numerous large fires that destroyed large portions of major cities. These fires were greatly responsible for the development of fire test methods, the standardization of those methods, and the enforcement of building codes based on the test methods. Some of these fires were the great fires of New York City (December 16,

\footnotetext{
${ }^{20}$ J. L. Gay-Lussac, Ann. Chim. Phys., 18 (No. 2, p. 211 ), 1821.
} 
1835); Chicago (October 8-9, 1871); the Boston fire (November 9, 1872); Baltimore (February 7, 1904), and the great San Francisco fire (April 18, 1906). ${ }^{21}$

\section{Testing for Fire Sprinklers}

Early fire testing in North America was generally associated with large-scale fire conditions in which large full-size assemblies or buildings were burned and evaluated. The earliest fire testing in North America appears to have come from the evaluation of fire protection systems in industrial facilities. Specifically, sprinkler systems were being installed in cotton mills, and in 1884 the Massachusetts Institute of Technology and the Boston Board of Fire Underwriters carried out a series of tests to evaluate sprinkler systems. ${ }^{22}$ This and other work led to the founding of the National Fire Protection Association (NFPA established in 1896) and its development of extensive test methods and standards for sprinkler systems. ${ }^{22 a}$ This was a landmark effort that established the use of active methods for controlling unwanted fires. Additionally and potentially equally as important, the use of sprinklers inside buildings implies that fire protection professionals of the period recognized that building contents were an important part of the fire growth problem. However, this concept was not articulated in any of the early reference materials studied for this paper. These documents typically focused on the sprinkler systems and fire performance of structural components.

\footnotetext{
${ }^{21}$ National Fire Protection Association, "Deadliest.large-loss fires, 25 largest fire losses in U.S. history," http:/ www.nfpa.org/itemDetail.asp?categoryID=954\&itemID=23352\&URL=Research\%20\&\%20Reports/ Fire\%20statistics/Deadliest/large-loss\%20fires, July 2008.

${ }^{22}$ Bond, Horatio, "Research on Fire," National Fire Protection Association International, Boston, MA, 1957.

${ }^{22 a}$ Grant, Casey C., "The Birth of NFPA,” NFPA Journal, National Fire Protection Association International, 1996.
} 


\section{Structural Component and Fire Endurance/Resistance Testing}

The large city fires that destroyed buildings and caused buildings to collapse were apparently at the forefront of fire protection thinking. Fire tests for the Denver Equitable Building appear to have been the first North American fire tests related to a building's floor system and structural performance. These tests were conducted in Denver, $\mathrm{CO}$, in $1890{ }^{23}$ The tests included load, shock, fire and water and continuous fire testing. ${ }^{23}$ In 1894, William H. Merrill established the Underwriters Electrical Bureau, now Underwriters Laboratories Inc., with the goal to investigate and help eliminate the causes of fires. On March 24, 1894, the Bureau released its first test report. ${ }^{24}$ Additionally in 1895, the Chicago Sanitary District established some of the earliest small-scale thermal tests related to fire exposure. These thermal tests were conducted on briquettes of neat cement and mortar.

Apparently, the earlier Great New York City fire of 1835 and other fires in the city that followed had an impact on the development of the first known fire test method to be specified by law in North America. This fire test method for testing "fire-proofing" for floor arches used in buildings was established by the state of New York, in 1896. The city of New York made the state fire test requirements a part of the city building code in $18999^{23}$

Two prominent fire test methods that are still being used were under development, in 1903. One of these was developed by Underwriters' Laboratories, Inc. ${ }^{25}$ This fire test

\footnotetext{
${ }^{23}$ Shoub, Harry, "Early History of Fire Endurance Testing In The United States," ASTM Special Technical Publication No. 301, Symposium on Fire Test Methods, American Society of Testing and Materials, Philadelphia, PA, 1961

${ }^{24}$ Underwriters Laboratories Inc., http://www.ullatinamerica.com/industry/en ulla_industry fireprotection.aspx, 2008.

${ }^{25}$ American Society for Testing and Materials International, ASTM E108-07a, Standard Test Method for Fire Tests of Roof Coverings, West Conshohocken, PA, 2007.
} 
designed for the protection of urban buildings from fire included evaluations for ignition, fire spread, and penetration of exterior roofing materials. The fire test method was adopted in 1910 by the National Fire Protection Association for the classification of roof coverings. This test has been in use for about 100 years and has been updated with advancements in technology and is currently ASTM E108, Standard Test Methods for Fire Tests of Roof Coverings. ${ }^{25}$ Test methods in this standard are utilized in the protection of homes particularly in communities where wildland/urban interfaces exist. The second fire test method originated in recommendations from the 1903 London meeting of the International Fire Prevention Congress. ${ }^{26}$ This test method dealt with the ability of building construction systems and structural members to endure fire exposure. In 1914, the NFPA Committee on Fire-Resistive Construction brought the fire endurance test method forward for action, and a revised form of the method was adopted in 1918 as NFPA $251{ }^{26}$ Currently, the test method is maintained by the NFPA Committee on Fire Tests which was established, in $1953 .^{27}$

Largely as a result of the Baltimore fire in 1904, ASTM (established in 1898) organized Committee P, the predecessor of Committee E 5. ${ }^{23}$ This committee provided a formal structure which contributed to the development of fire test methods, and within a year it had prepared proposals for fire endurance testing of floors. ${ }^{23}$ At this time, the fire testing station at Columbia University and the U.S. Geological Survey were evaluating fire endurance testing. During the period from 1906 through 1907, the U. S. Geological Survey conducted fire tests using a gas fired furnace for testing a number of different

\footnotetext{
${ }^{26}$ National Fire Protection Association, NFPA 251 Standard Methods of Tests of Fire Resistance of Building Construction and Materials, Quincy, MA, 2006

${ }^{27}$ National Fire Protection Association, "Year Book, National Fire Protection Association, Articles of Association Officers and Committees 1953-1954," Boston, MA, October 1953.
} 
building materials. These tests were reported by R. L. Humphrey in Geological Survey Bulletin 370, in $1909 .^{23}$

In 1908, the American Society for Testing and Materials adopted their first fire test for floors, and in 1909 ASTM also adopted a fire test method for partitions. Work on these fire tests and others for the protection of structural columns, in 1918, eventually led to the establishment of a testing protocol that was the forerunner of the ASTM E1 19 test standard. ${ }^{28}$ This work was carried out by ASTM Committee C-5. Work by S. H. Ingberg, of the U. S. National Bureau of Standards, NBS, (now the National Institute of Standards and Technology, NIST), Underwriters' Laboratories, the Associated Factory Mutual Fire Insurance Company, and others helped to further develop large-scale test methods that were finally adopted in 1933 and ultimately became ASTM E1 19, Standard Method of Fire Tests of Building Construction and Materials. ${ }^{23,28}$ For further information on building fire resistance testing, the reader should also review a paper by Babrauskas and Williamson, entitled, "The Historical Basis of Fire Resistance Testing Part I and Part II. ${ }^{29}$ (Figure 2)

\footnotetext{
${ }^{28}$ Robertson, A. F., "Roots and History of Committee E-5," ASTM Standardization News, Volume 9, Number 12, American Society for Testing and Materials, Philadelphia, PA, pp. 14-20. December 1981. ${ }^{29}$ Babrauskas, Vytenis and Williamson, Robert Brady, "The Historical Basis of Fire Resistance Testing Part I and Part II," Fire Technology, Volume 14, No. 3 pp. 184-251 and No. 4 pp. 304-316, Boston, MA, 1978.
} 

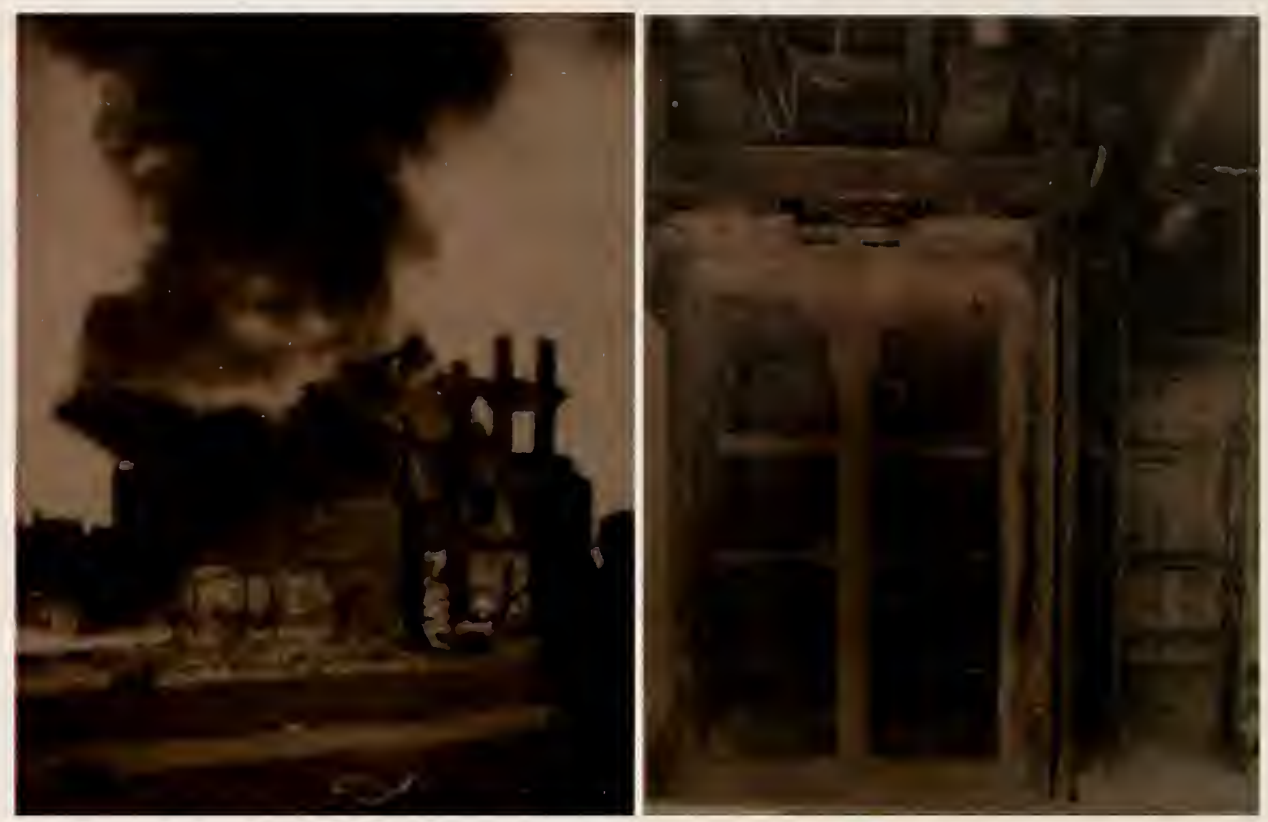

Figure 2 NBS Federal Triangle fire test (left) \& NBS column furnace (right), 1920 s.

\section{Second Revolution in Fire Testing - Data Recording Machines/Knowledge Growth}

The second revolution in fire testing began during the early part of the twentieth century and was based on the ability to use machines to automatically and remotely record fire test data. This advancement in data recording allowed detailed study of quantitative transient fire behavior. Therefore, fire researchers of the period had the ability to more accurately measure fire behavior which supported a rapid acceleration in fire dynamics knowledge. During this same time period, fire researchers throughout the world were applying this new knowledge to improve scientifically based fire test methods and standards.

\section{Early Small-Scale Fire Tests}

From the above discussion it would appear that the only fire tests being developed were large-scale tests. However, the testing of small quantities of building materials to 
measure their combustible properties was underway as early as $1912 .^{30}$ R.E. Prince developed a furnace apparatus designed for studying the ignitability of various species of wood and to investigate the effect of fire-retardant treatments on the ignition of wood. ${ }^{30}$ This test methodology was further developed over several decades by the British Standards process (1932), S.H. Ingberg (1945), and N.P. Setchkin (1949). ${ }^{30}$ A form of the fire test method was adopted by ASTM Committee D20 as Test Method D1929 as a tentative standard for the evaluation of plastics. The test method continued to be used and studied and ultimately was adopted as a fully recognized standard as ASTM Test Method E136, in $1958 .^{30}$ This small-scale fire test addressed the combustibility of materials and posed the question, will materials produce heat and flame if exposed to high temperatures?

\section{Building Contents and Surface Flammability of Materials Test Methods}

The importance of the contribution of building contents apparently was first addressed during the period between 1918 and 1924 following a series of deadly nitro-cellulose movie film fires in theaters and film exchange buildings. The NFPA Quarterly of July 1924 reported tests to evaluate the combustibility of movie film. ${ }^{31}$ In the April 1925 NFPA Quarterly, a brief story described a fire on Christmas Eve in which interior decorations and room contents caused the death of 36 people, in Babb Switch, OK. ${ }^{32}$

\footnotetext{
${ }^{30}$ American Society for Testing and Materials International, ASTM E136-04 Standard Test Method for Behavior of Materials in a Vertical Tube Furnace at $750^{\circ} \mathrm{C}$, West Conshohocken, PA. 2007.

${ }^{31}$ National Fire Protection Association, "Film Burning Tests," NFPA Quarterly, Vol. 18, No. 1, Boston, MA, July 1924.

${ }^{32}$ National Fire Protection Association, “It Did NOT Burn," NFPA Quarterly, Vol. 18, No. 4, Boston, MA, April 1925.
} 
Surface flammability of interior finishes, including flooring, apparently was addressed in 1926, as reported by the NFPA Quarterly. ${ }^{33}$ The danger from interior finishes was emphasized again during the 1940s by fires such as the Coconut Grove night club fire (1942), the Winecoff, La Salle, and Canfield Hotels fires of 1946, and the St. Anthony Hospital fire of $1949 .{ }^{34}$ Each of these fires had heavy loss of life and extensive property damage resulting in large financial losses. As a result of theses fires S. H. Ingberg (NBS) and A. J. Steiner (of Underwriter's Laboratories) took on the challenge to develop a fire test method for measuring the fire performance of finishes and flooring materials. This work saw the development of a large flame-spread tunnel furnace which eventually became an Underwriters' Laboratory test method in 1944 and also became ASTM E84 (in 1950), and was adopted by NFPA as Standard No. $255 .{ }^{34}$ (Figure 3)

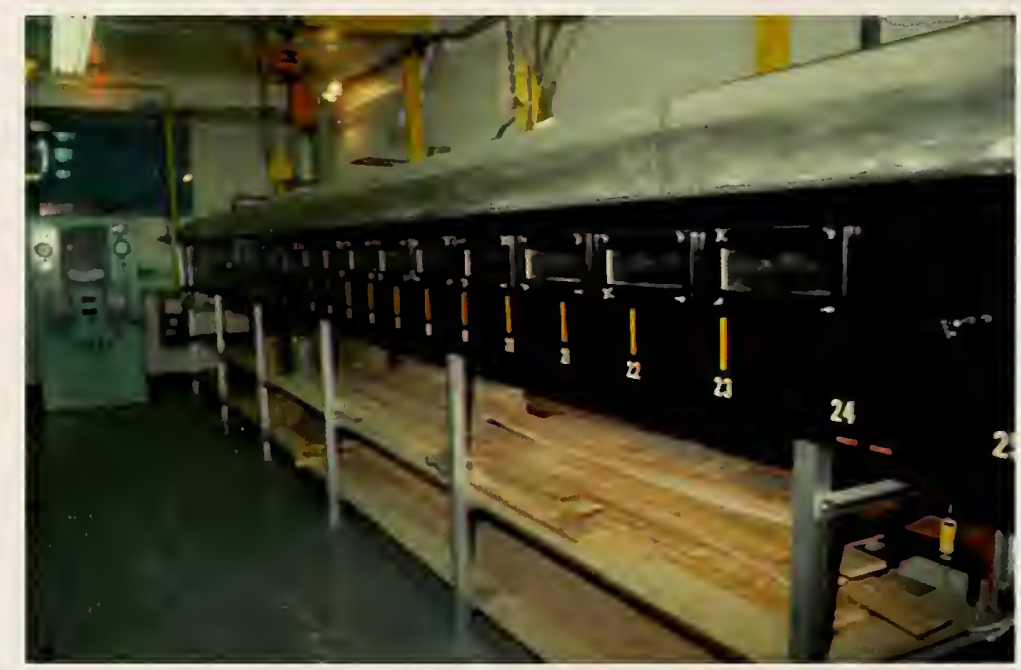

Figure 3 Photograph of Tunnel Test Apparatus, ASTM E84, NFPA 255, \& UL 723

\footnotetext{
${ }^{33}$ National Fire Protection Association, "Plastic Floor Coverings," NFPA Quarterly, Vol. 19, No. 3, Boston, MA, January 1926.

${ }^{34}$ Yuill, Calvin H., "Flame-Spread Tests in a Large Tunnel Furnace," Symposium on Fire Test Methods (1962), American Society for Testing and Materials, Philadelphia, PA, 1962.
} 
The development of large-scale fire test methods had its negative side. Many users of the test methods were concerned about the cost of fabrication and testing of materials and pushed for small-scale tests that could be used for screening materials. This resulted in the development of two surface flammability tests that were much smaller than the largescale tunnel. One of these tests was developed by the U.S. Department of Agriculture, Forest Products Laboratory, in $1951 .^{35}$ This test was referred to as the FPL 8-FT Tunnel Method. The test is similar to the ASTM E84 test, but is much smaller. The second test method of interest is the surface flammability test using a radiant-panel method developed by NBS. This test method was adopted by ASTM as E162, in $1962 .{ }^{36}$ The test method uses specimens that measure less than a meter in length. These two tests have primarily been used to measure the surface flammability of wall and ceiling materials. Underwriters Laboratories has a modified version of the ASTM E84 test (UL 992) that has been used to evaluate the fire behavior of flooring materials. ${ }^{37}$ Traditionally, flooring used in commercial buildings, hospitals, nursing homes and other public buildings were made from wood, vinyl asbestos tile, terrazzo, and linoleum. These materials had little affect on fire growth and the spread of fire in a building. However, in the 1950s and 1960s carpet became competitive with the traditional flooring and gained popularity. As this occurred, some fire officials became concerned about the possibility that carpet helped to spread fire throughout buildings. ${ }^{37}$ As a result, in 1965 , efforts were made to study the flame spread phenomenon associated with carpet, and by

\footnotetext{
${ }^{35}$ Peters, C.C., and Eickner, H.W., "Surface Flammability as Determined by the FPL 8-ft Tunnel Method, Symposium on Fire Test Methods (1962), American Society for Testing and Materials, Philadelphia, PA, 1962.

${ }^{36}$ Robertson, A.F., "Surface Flammability Measurements By The Radiant-Panel Method," Symposium on Fire Test Methods (1962), American Society for Testing and Materials, Philadelphia, PA, 1962.

${ }^{37}$ Benjamin, I. A. and Davis, S., "Flammability Testing for Carpet," Fire Technology, Vol. 15, No. 3, August 1979.
} 
April 1970 the first fire test for carpet was established, the "Pill Test" DOC FF 1-70..$^{36,37}$ However, before this requirement for testing carpet materials could go into effect, a serious life loss fire occurred in a nursing home in Marietta, Ohio. ${ }^{38}$ In this fire, it was found that the floor covering materials contributed to the flame spread in the corridors and to the loss of life in the nursing home. This finding helped to confirm concerns that floor covering materials needed additional testing beyond the "Pill Test." The "Pill Test" was conducted in a laboratory room environment in which there was no external thermal flux applied to a test specimen. Therefore, the test condition was not representative of fire environments where flooring materials would typically receive radiant energy from a growing fire. ${ }^{38}$ Over the period from 1966-1974, another fire test method for flooring materials was being developed. This test apparatus became the "Flooring Radiant Panel" and it originated with work by Zabowaky at Armstrong Cork Company, in $1966 .{ }^{38}$ At the same time that Armstrong was working on the test apparatus, the National Bureau of Standards was carrying out a research effort to better quantify fire behavior in building corridors. ${ }^{39}$ The work by Denyes and Quintiere developed knowledge associated with an important flame spread parameter which was named "critical radiant flux." The work by Armstrong and NBS merged and Howard Adams (NBS Research Associate from the Monsanto Company representing the Society of Plastics Industry) finalized the effort and prepared the draft test procedure that was ultimately adopted in 1978 as ASTM E648. ${ }^{38,40}$

\footnotetext{
${ }^{38}$ Adams, A. Howard, "Flooring Radiant Panel Test, Proceedings, "Fire_Retardency in the Interior Furnishing Industry, Fire Retardant Chemical Association, Lancaster, PA, March 1976.

${ }^{39}$ Denyes, Wells and Quintiere, James, "Experimental and Analytical Studies of Floor Covering Flammability with a Model Corridor," NBSIR 73-199, National Bureau of Standards, Gaithersburg, MD 1973.

${ }^{40}$ American Society for Testing and Materials, "E648, Standard Test Method for Critical Radiant Flux of Floor-Covering Systems Using a Radiant Heat Energy Source," ASTM International, West Conshohocken, PA, 2008.
} 
A modified version of the E648 test method has also been applied to the measurement of flame spread from thermal insulation materials and was adopted in 1983 as ASTM E970. ${ }^{41}$

\section{Smoke and Fire Toxicity Test Methods}

The effects of smoke from fire were likely recognized to be a problem by early humans who may have been exposed to it from fires in their environment. It was surely apparent to early humans when they stood down-wind of a fire used for cooking, light, or protection. It can be visualized from one's own experience at a camp fire that smoke likely irritated the eyes of these early humans, and they likely rationalized that smoke could be harmful. In 1823 , the danger of smoke inhalation during fire fighting aboard ships was recognized by Charles A. Deane (a British shipyard caulker and inventor of underwater diving equipment), and as a result, he patented one of the first functional breathing apparatus called the "Smoke Helmet." ${ }^{, 2}$ In North America, protection from smoke typically was addressed for buildings in which large numbers of people would be located. Manufacturing plants and schools received much of the attention. The April 1913, Quarterly of the National Fire Protection Association published and article entitled, "The Fireman as an Educator." This article proposed a school curriculum for fire prevention and control, and a part of it suggested how to use woolen head coverings and wet towels to avoid inhalation of smoke..$^{43}$ In 1918, Benjamin Richards of the National

\footnotetext{
${ }^{41}$ American Society for Testing and Materials, "E970, Standard Test Method for Critical Radiant Flux of Exposed Attic Floor Insulation Using a Radiant Heat Energy Source," ASTM International, West Conshohocken, PA, 2008.

${ }^{42}$ Newton, William and Partington, Charles Frederick, "Charles Anthony Deane - 1823 patent," Newton's London Journal of Arts and Sciences 9, 1825.

${ }^{43}$ Hyman, Julius; "The Fireman as an Educator," Quarterly of the National Fire Protection Association, Vol. 6, No. 4, Boston, MA, April 1913.
} 
Fire Protection Association suggested that there should be standardization of school buildings for fire protection. His writings included the following statement: "The danger from smoke calls for special consideration from a life safety standpoint, so special care is necessary in planning exits." ${ }^{\text {44 }}$ In 1933, George Ferguson described the significance of smoke and various fire gases to life safety in an article published in the NFPA Quarterly. ${ }^{45}$

By 1944, Underwriters Laboratories' large surface flame spread tunnel referred to as the "Steiner Tunnel" (later UL 723 \& ASTM E84) addressed the issue of smoke, and it was potentially the first formal test method to include a means to measure smoke produced from a burning test material. The test apparatus vent pipe included a light beam and photo-electric cell that measured smoke production; additionally, the documentation for the test method stated that gas samples could be withdrawn from the vent pipe for determining toxicity and other properties. ${ }^{46}$ Finally in 1964 , a report was published describing the first fire test method that specifically attempted to address smoke hazards. ${ }^{47}$ This test (developed by the Rohm and Hass Co., of Philadelphia, PA) was designed to measure smoke density in relationship to a human's ability to view an exit sign in a smoky environment produced by a burning test material. In 1966, the U. S. National Bureau of Standards presented a paper on a similar fire test method for

\footnotetext{
${ }^{44}$ Richards, Benjamin; "Standardization of School Buildings," Quarterly of the National Fire Protection Association, Vol. 12, No. 1, Boston, MA July 1918.

${ }^{45}$ Ferguson, George; "Fire Gases," Quarterly of the National Fire Protection Association, Vol. 27, No. 2, Boston, MA, October 1933.

${ }^{46}$ A. J. Steiner, "Fire Hazard Classification of Building Materials," Underwriters Laboratories, Inc., Bulletin of Research No. 32, Chicago, IL, September 1944.

${ }^{47}$ National Fire Protection Association, "A Method of Measuring Smoke Density," Quarterly of the National Fire Protection Association, Vol. 57, No. 3, Boston, MA, January 1964.
} 
measuring smoke from burning materials. ${ }^{48}$ This NBS test method eventually was adopted, in 1979, by ASTM as the E662 Standard Test Method for Specific Optical Density of Smoke Generated by Solid Materials. ${ }^{49}$ This ASTM standard has been extensively used in the transportation industry through regulations from the United States, Federal Railroad Administration (FRA) and the Federal Aviation Administration (FAA). Additionally, ASTM E662 has been referenced by the NFPA, National Electrical Code.

Computer modeling of fire dynamics and the need to predict the changing smoke environment produced by fire has helped to advance smoke measurement technology. These technological demands have resulted in the development of a smoke test method that can, in addition to measuring specific optical density, measure the mass optical density of smoke produced by burning materials. Much of the original work on the development of this test method was done in Europe and was adopted by North American researchers. This test apparatus took advantage of increased knowledge and technological advancements in its design and construction. In 1998, ASTM approved the new standard, E1995, Standard Test Method for Measurement of Smoke Obscuration Using a Conical Radiant Source in a Single Closed Chamber, With the Test Specimen Oriented Horizontally. ${ }^{50}$ As mentioned in the standard's title, the apparatus employs a conical thermal radiation source, and additionally, it has a load cell for measuring mass loss rate.

\footnotetext{
${ }^{48}$ Gross, D.; Loftus, J.J.; and Robertson, A.F., "Method for Measuring Smoke from Burning Materials," Symposium on Fire Test Methods - Restraint \& Smoke1966, ASTM STP 422, American Society for Testing and Materials, p. 166, 1967.

${ }^{49}$ American Society for Testing and Materials, "E662, Standard Test Method for Specific Optical Density of Smoke Generated by Solid Materials," ASTM International, West Conshohocken, PA, 2006.

${ }^{50}$ American Society for Testing and Materials, "E1995 Standard Test Method for Measurement of Smoke Obscuration Using a Conical Radiant Source in a Single Closed Chamber, With the Test Specimen Oriented Horizontally," ASTM International, West Conshohocken, PA, 2004
} 


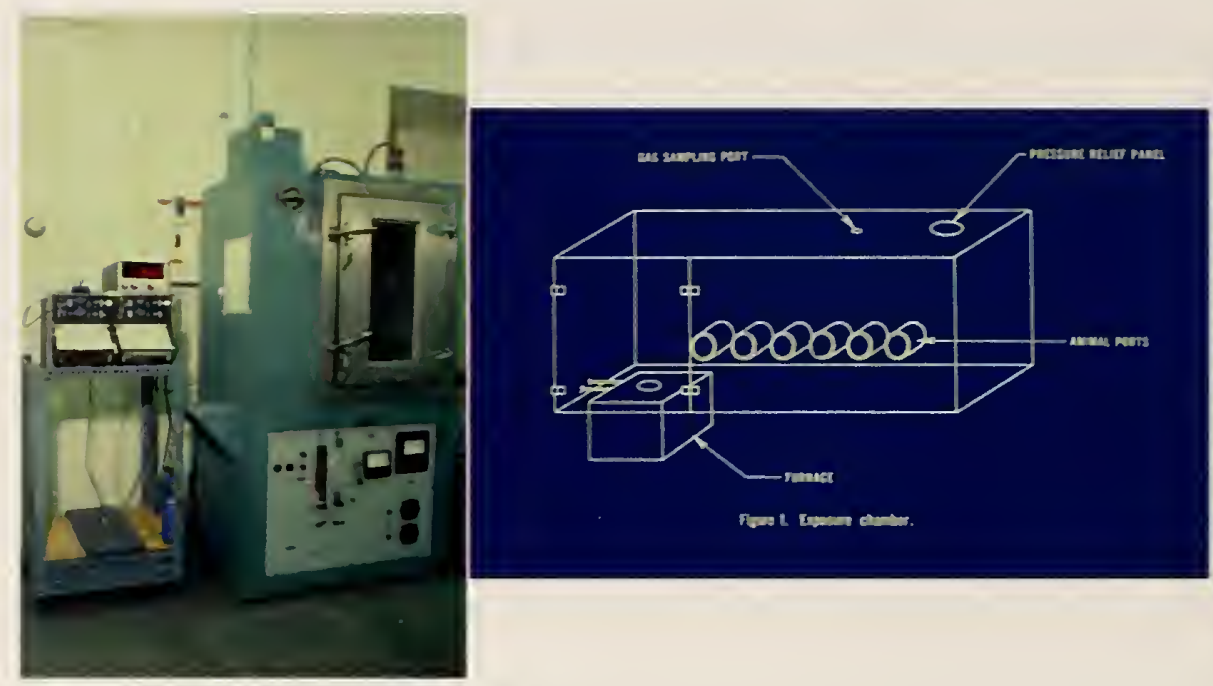

Figure 4 NBS Smoke Chamber (left) \& Sketch of Toxicity Test Chamber (right).

From the earlier discussion, the fact that combustion products from fire are toxic has likely been known for thousands of years. However, many of the scientific tools and the knowledge needed to explain why smoke and combustion gases are toxic were not available until the $19^{\text {th }}$ and $20^{\text {th }}$ century. Therefore, an in-depth understanding of fire toxicity did not occur until the early to mid-1900s. Work by numerous researchers in the 1960s and 1970s directly addressed the issue of fire toxicity. A sampling of studies by Zikria, "Smoke poisoning in fires," Einhorn, "Smoke and survival during fire exposure,"52 and Reinke and Reinhardt, "Fires, toxicity and plastics" issue of fire toxicity to the forefront. At the time, industry based research on fire toxicity was also underway by companies such as Weyerhaeuser and industry members of the

\footnotetext{
${ }^{51}$ Zikria, B.A., "Smoke poisoning in fires," Polym. Prepr., Vol. 14, pp. 1017-1021, 1973.

${ }^{52}$ Einhorn, I.N., "Smoke and survival during fire exposure," Polym. Prepr., Vol. 14, pp. 1001-1009, 1973.

${ }^{53}$ Reinke, R.A. and Reinhardt, D.F., "Fires, toxicity and plastics," Modern Plastics, Vol. 4, pp. 94-99, 1973.
} 
Society of Plastics Industry. ${ }^{54}$ Research efforts continued throughout the 1970 s and from these studies two fire test methods for fire toxicity emerged. One of these test methods grew from a NBS research grant to the University of Pittsburgh which resulted in a paper by Alarie and Barrow. ${ }^{55}$ This test method developed at Pittsburgh is known as the "University of Pittsburgh Method" and is currently in use. The other fire toxicity test method began as a joint effort between the Southwest Research Institute (SwRI) and the National Bureau of Standards. NBS further developed the test method, and it was adopted by ASTM as a test method for fire toxicity, in $1995 .^{56}$ (Figure 4)

\section{Heat Release Rate Calorimetry}

In the 1950s, the study of fires and fire growth identified that the burning rate and heat release rate of materials were critical factors associated with fire growth. The study, by Factory Mutual Laboratories, of a disastrous industrial plant fire in 1953, where insulated roof deck was a primary contributor helped to identify that heat release rate of burning materials was a critical issue. ${ }^{57}$ As a result, Factory Mutual Laboratories, by 1959 , developed the first heat release calorimeter known to be located in North America. Additionally, in 1959 Howard Emmons of Harvard University published an article which highlighted the need to quantify the "Total rate of energy release vs. time" and the

\footnotetext{
${ }^{54}$ American Society for Testing and Materials, "E1678-02, Standard Test Method for Measuring Smoke Toxicity for Use in Fire Hazard Analysis," ASTM International, West Conshohocken, PA, 2008

${ }^{55}$ Alarie, Yves, and Barrow, Craig, "Toxicity of Plastic Combustion Products. Toxicological Methodologies to Assess the Relative Hazards of Thermal Decomposition Products from Polymeric Materials," NBS-GCR-77-85, National Bureau of Standards, February 1977.

${ }^{56}$ Levin, B.C., et. al., Further Development of a Test Method for the Assessment of the Acute Inhalation Toxicity of Combustion Products," NBSIR 82-2532, National Bureau of Standards, Gaithersburg, MD, June 1982. ASTM E 1678-02.

${ }^{57}$ Thompson, Norman J. and Cousins, E. W., "The FM Construction Materials Calorimeter" Quarterly of the National Fire Protection Association, Vol. 52, No. 3, Boston, MA, January 1959.
} 
"Space-distribution of energy release rate. ${ }^{.58}$ These two efforts helped to raise the status of heat release rate calorimetry to a high level of importance.

Major strides in heat release rate calorimetry were not made in North America until the early 1970s. Two efforts were underway at this time. One was led by E. E. Smith of Ohio State University and the second was led by W. J. Parker of the U. S. National Bureau of Standards. ${ }^{59,60}$ The "Smith Calorimeter or Ohio State Calorimeter," operated through measurements using differential thermocouples in the combustion product gas flow, and the "NBS Calorimeter," operated as a constant temperature device with the proportional lowering of a metered auxiliary combustion gas flow equaling the heat release of the test specimen. ${ }^{60}$ Data from these two systems were gathered by strip chart recorders, and the heat release rates would be determined from the data following the test. The "Smith Calorimeter" progressed through the standards process and became ASTM E 906, Standard Test Method for Heat and Visible Smoke Release Rates for Materials and Products Using a Thermopile Method. Even though these methods provided insight into the burning behavior of materials, their convective enthalpy measurements failed to capture radiant loss and heat loss to the apparatus walls. The introduction of the computer age in fire testing provided the basis for more advanced methods of measuring heat release rates from burning materials.

\footnotetext{
${ }^{58}$ Emmons, Howard W., "A U. S. Program of Fire Research," Quarterly of the National Fire Protection Association, Vol. 52, No. 3, Boston, MA, January 1959.

${ }^{59}$ Smith, E.E., "Heat Release Rate of Building Materials," STP502, American Society for Testing and Materials, Philadelphia, PA, 1971.

${ }^{60}$ Parker, W.J. and Long, M.E., "Development of a Heat Release Rate Calorimeter at NBS," STP502, American Society for Testing and Materials, Philadelphia, PA, 1971.
} 


\section{Third Revolution in Fire Testing - Computer Data Collection/Analysis Tools}

The third revolution in fire testing (measurement technology) occurred in the last half of the twentieth century with the development of affordable desktop digital computers, data logging, computer aided data analysis, and scientifically based predictive models. Through acquisition of quantitative time-related data, digital computing has opened the theoretical world that provides insight into the subtle features of fire dynamics and provides a means for developing a greater understanding of fire test method performance. These computer based advancements led to new test methods that likely would not have been possible without the development of these innovative tools. Today, many fire tests are conducted using high-speed, data-logging, lightweight, portable computers that are more powerful than many room size mainframe computers that were being used less than 20 years ago. These tools have spurred a growth in fire physics and fire chemistry knowledge which has allowed for the rapid development and validation of fire theory, fire models, and fire tests methods based on the new capabilities. One of the significant advancements emerging from this revolution was the development of oxygen consumption calorimetry. (Figure 5) 


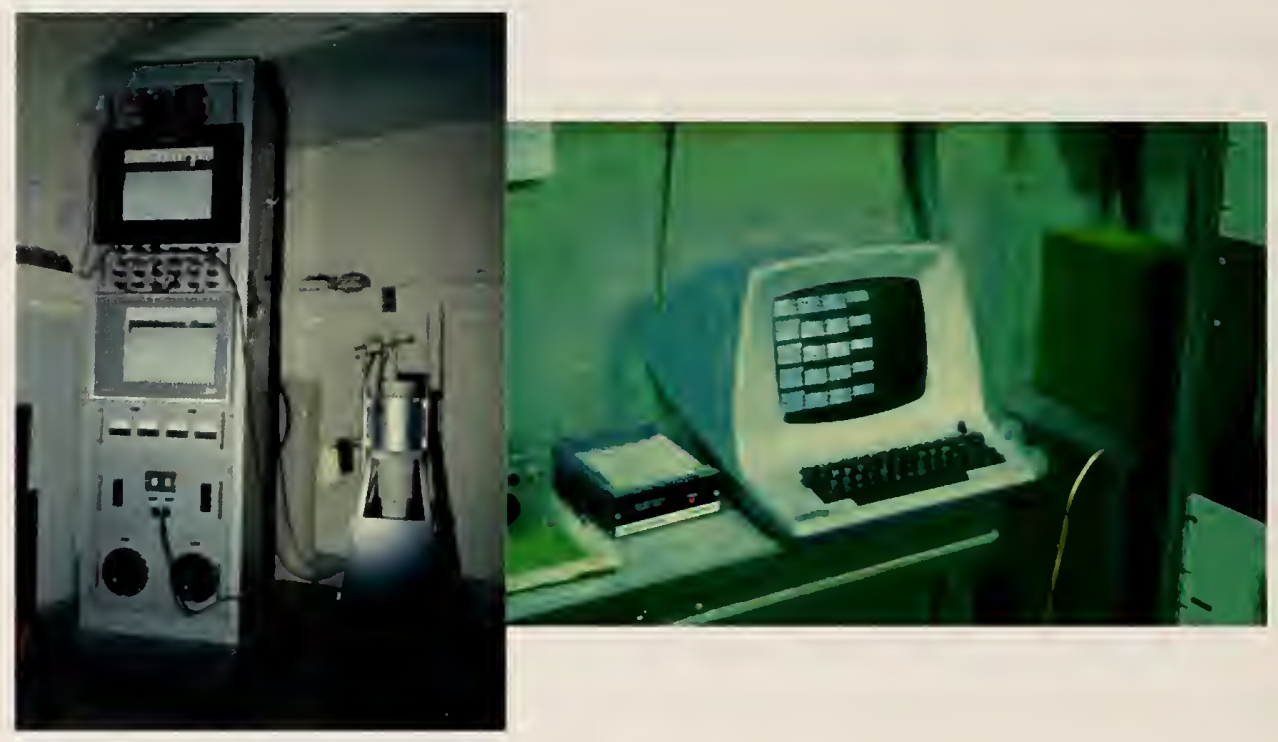

Figure 5 Photographs of strip chart recorders (left) and computer terminal (right).

Note in the figure above, the two strip chart recorders are taking temperature data from the combustibility furnace located to the right. Also, the computer terminal shows data sets being recorded from an oxygen consumption calorimeter fire test.

\section{Oxygen Consumption Calorimeter Heat Release Rate Test Methods}

In 1977, Beason and Alvares of Lawrence Livermore Laboratory reported that they experimented with a procedure using oxygen consumption to study the burning of wood and plastic cribs in a room with limited room ventilation. ${ }^{61}$ Along the same period of time, Parker of NBS was also using oxygen consumption techniques to investigate the fire environment inside the Underwriters Laboratories ASTM E84 (UL 723) tunnel test apparatus. $^{62}$ Techniques used by both efforts were based on the original work of W. M. Thornton who published a paper on the relation of oxygen to the heat of combustion of

\footnotetext{
${ }^{61}$ Beason, D.G. and Alvares, N.J., "Variations in the Burning Characteristics of Low Porosity Cribs," Combustion Institute/Western States Section, Spring 1977.

${ }^{62}$ Parker, W. J., "An Investigation of the Fire Environment in the ASTM E 84 Tunnel Test," NBS Technical Note 945, National Bureau of Standards, August 1977.
} 
organic compounds. ${ }^{63}$ In 1978, Clayton Huggett of the National Bureau of Standards focused an effort on defining a body of science necessary for the development of a robust oxygen calorimeter system. In December of that year, he presented a paper to the Combustion Institute/Eastern States Section entitled "Oxygen Consumption Calorimetry." ${ }^{64}$ This paper established the basis for the refinement and development of future fire test methods using oxygen consumption calorimetry. Concurrently, William Parker a colleague of Huggett at NBS was busy putting the calorimetry concept into practice. Parker with another colleague Darryl Sensenig, a NBS Research Associate from Armstrong Cork Company, built and tested the first bench-top oxygen consumption heat release rate calorimeter. ${ }^{65}$ This bench-top calorimeter was the fore-runner to the current "Cone Calorimeter," ASTM E1354. ${ }^{66}$

\footnotetext{
${ }^{63}$ Thornton, W.M., "The Relation of Oxygen to the Heat of Combustion of Organic Compounds," Phil. Mag. 33, pp. 196-203, 1917.

${ }^{64}$ Huggett, Clayton, "Oxygen Consumption Calorimetry," Fall Technical Meeting on Chemical and Physical Processes in Combustion, Combustion Institute/Eastern States Section, Pittsburgh, PA, December 1978.

${ }^{65}$ Sensenig, D.L. and Parker, W.J., "New Concept for Rate of Heat Release Measurements by Oxygen Consumption," The Combustion Institute/Eastern Section, Pittsburgh, PA, December 1978.

${ }^{66}$ American Society for Testing and Materials, "E1354-04, Standard Test Method for Heat and Visible Smoke Release Rates for Materials and Products Using an Oxygen Consumption Calorimeter," ASTM International, West Conshohocken, PA, 2007.
} 

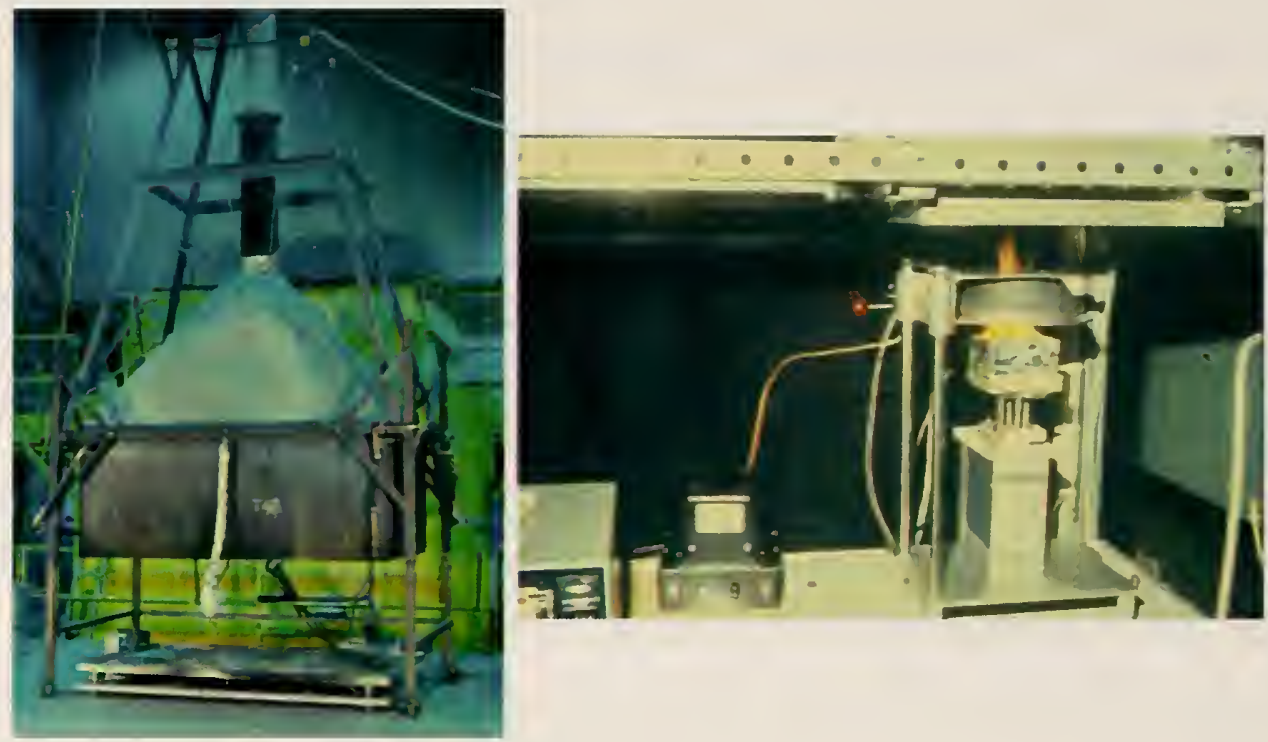

\section{Figure 6 First $\mathrm{O}_{2}$ Consumption Calorimeters, Furniture Calorimeter (left) \& Cone}

\section{Calorimeter (right)}

Oxygen consumption calorimetry may be recognized as one of the most important developments in fire testing. It has provided a tool to help measure fire behavior at the two extremes of fire testing, bench-scale and large-scale levels. In 1982, NBS reported on the development of a large-scale oxygen consumption calorimeter used for measuring the heat release rate of furniture. ${ }^{67}$ Additionally in 1982, Babrauskas of NBS published a second paper on the development of a bench-scale heat release rate calorimeter (the Cone Calorimeter) also using the oxygen consumption technique. ${ }^{68}$ (Figure 6) The utility and performance of the "NBS Furniture Calorimeter" was demonstrated by Lawson, Walton and Twilley in a report that described the evaluation of 23 different interior furnishings,

\footnotetext{
${ }^{67}$ Babrauskas, Vytenis; Lawson, J. Randall; Walton, W.D.; and Twilley, William H.; "Upholstered Furniture Heat Release Rates Measured with a Furniture Calorimeter," NBSIR 82-2604, National Bureau of Standard, Gaithersburg, MD, 1982.

${ }^{68}$ Babrauskas, V., "Development of the Cone Calorimeter - A Bench Scale Heat Release Rate Apparatus Based on Oxygen Consumption," NBSIR 82-2611, National Bureau of Standards, Gaithersburg, MD, 1982.
} 
including items such as easy chairs, sofas, bookcases, wardrobe closets, and bedding. ${ }^{69}$

Also, NBS and others were applying oxygen consumption calorimetry to the measurement of heat release rate in large-scale room fire tests. ${ }^{70}$ Since this developmental work, the oxygen consumption heat release rate measurement technique has been further refined by Parker, Babrauskas, Janssens ${ }^{71}$ and others, and it has become a critical measurement tool as a part of more than a dozen small-scale, intermediate-scale, and large-scale fire test method standards in North America and throughout the world. These test methods are found as ASTM, NFPA, and ISO (International Standards Organization) standards.

\section{Fire Test Methods Addressing Furniture Ignition and Bedding Fires}

Over the decades during the 1800s and 1900s, it was widely known that smoking of tobacco products, particularly cigarettes, often was associated with the cause of serious fires. As a result, in the late 1900s work was carried out by the NIST with funding from the U.S. Consumer Product Safety Commission (CPSC) to develop a means to measure the ignition propensity of cigarettes. CPSC's plan was that new standards could be developed that would help reduce the number of fire deaths related to cigarette smoking. The effort led by Ohlemiller and Gann brought the new test method into existence. ${ }^{72}$ It is a bench-scale fire test designed to measure the ignition strength of cigarettes. This test

\footnotetext{
${ }^{69}$ Lawson, J.R.; Walton, W.D.; and Twilley, W.H.; "Fire Performance of Furnishings as Measured in the NBS Furniture Calorimeter, Part 1," NBSIR 83-2787, National Bureau of Standards, Gaithersburg, MD, January 1984.

${ }^{70}$ Sensenig, D., "An Oxygen Consumption Technique for Determining the Contribution of Interior Wall Finishes to Room Fires," NBS Technical Note 1182, 1980.

71 M.L. Janssens, "Measuring Rate of Heat Release by Oxygen Consumption," Fire Technology, Vol 27, pp. 234-49, (1991).

${ }_{72}$ Ohlemiller, T.J., Villa, K.M., Braun, E., Eberhardt, K.R., Harris, Jr., R.H., Lawson, J.R., and Gann, R.G., Test Methods for Quantifying the Propensity of Cigarettes to Ignite Soft Furnishings, NIST Special Publication 851, National Institute of Standards and Technology, Gaithersburg, MD, 1993.
} 
method is currently ASTM E2187, Standard Test Method for Measuring the Ignition Strength of Cigarettes. ${ }^{73}$ The test method was first adopted by the state of New York for regulating cigarette fire performance and has since been adopted by numerous other states, Canada, and a number of other countries around the world. Also, this work coupled with the development of fire test methods for determining the fire performance of mattresses (ASTM E1474 and E1590) ${ }^{74,75}$ is expected to have a positive impact on fires and life loss associated with bedding.

\section{New Opportunities - Short Term Needs in Fire Testing}

The above discussion provides a summary of the development of tools for creating fire test methods. It describes the needs that fostered the development of fire test methods. And, it describes the history associated with the development of North American fire test methods that have mostly become standard test methods used to help protect the public and property. It brings this history to the present, the beginning years of the $21^{\text {st }}$ Century, and it lays the groundwork for the future of fire test method development. At this point, it is time to attempt to look into the future. As the reader understands, the following discussion is strictly hypothetical, but it is based on perceived needs of the future and the possibility of additional advancements in engineering and science.

Fire measurement technology now has the scientific and computational tools to make significant advancements in the development of fire safety standards for materials,

\footnotetext{
${ }^{73}$ American Society for Testing and Materials, ASTM E2187, Standard Test Method for Measuring the Ignition Strength of Cigarettes, ASTM international, West Conshohocken, PA, 2004.

${ }^{74}$ American Society for Testing and Materials, "E1474-04, Standard Test Method for Determining the Heat Release Rate Of Upholstered Furniture and Mattress Components or Composites Using a Bench Scale Oxygen Consumption Calorimeter," ASTM International, West Conshohocken, PA, 2007.

${ }^{75}$ American Society for Testing and Materials, "E1590-07, Standard Test Method for Fire Testing of Mattress," ASTM International, West Conshohocken, PA, 2007.
} 
products, buildings, and transportation. Use of these tools has directed attention to improvements needed in fire testing. As demonstrated by the World Trade Center disaster, new approaches are needed for evaluating fire performance of the following items:

- Improvements are needed in fire tests of spray on and other thermal protection systems for structural members.

- Fire resistance testing is needed for structural member fastener systems while carrying a design load.

- Reduced scale fire resistance testing of fastener systems for structural members that produce accurate scalable results for full size assemblies.

- Fire resistance testing is needed that will accurately quantify the thermal and structural load carrying performance of long span beam and floor structural systems.

These items identify advancement needs for testing structural components, assemblies, and systems under realistically simulated fire and load conditions. The objective for these new tests would be to enhance structural performance so that uncontrolled building fires result in burnout without partial or total collapse.

In addition to the immediate needs in fire testing listed above, there will be a growing set of needs with advancements in technology and computational capability. As has been the case over the last decade or so, computer modeling has begun to influence the way that fire testing is conducted. There has been significant discussion concerning the types and quality of measurements needed for fire tests and how these data can be applied to 
computer models for estimating fire hazard. ${ }^{76,77}$ It is expected that this dialog will continue as fire test methods are honed to provide more accurate and usable results that are also applicable as input to predictive fire models. Based on current dialog, it is possible that fire testing will form two distinctly different paths. One path may maintain and continue to develop the traditional prescriptive fire test methods that relate to the safe use of materials and consumer products. The second path may develop standard fire test methods strictly focused on providing highly accurate data for predictive fire hazard models to be used in performance based codes and standards. An important part of this task, relative to the development of these fire test methods and their ability to provide accurate predictive results, will be to determine the required measurement accuracy for each measurement parameter. This will give the fire test developer the information necessary for designing an efficient and effective fire test method that will meet the modeling requirements. Ultimately, if these two different lines of fire test methods do evolve, it would be expected that eventually, with time, the predictive fire hazard test methods would survive, replacing the technically less robust prescriptive fire test methods. Additionally, fire test methods will continue to evolve based on measurement capability. As new measurement tools are developed that can be applied to fire testing, it is expected that new fire test methods will be developed that will apply the new technology. Also, advancements in computing and data analysis will likely open the way for the development of future fire test methods.

\footnotetext{
${ }^{76}$ Grosshandler, William (Editor); Hamins, Anthony and McGrattan, Kevin; "Advanced Fire Measurement and Predictive Methods," Workshop on Fire Testing Measurement Needs: Proceedings, NISTIR 6774, National Institute of Standards and Technology, Gaithersburg, MD, August 2001.

${ }^{77}$ American Society for Testing and Materials, "E1591-07, Standard Guide for Obtaining Data for Deterministic Fire Models," ASTM International, West Conshohocken, PA, 2007.
} 


\section{Additional Needs for Codes and Standards Based Fire Testing}

- Wildland/urban interface fires have destroyed thousands of homes and have also caused numerous fatalities. Building codes are being modified to address the issues of ignitions and burning of homes and other buildings. New fire test methods are likely to be required for measuring the ignition and fire performance of materials and systems designed to prevent the ignition and burning of buildings during exposures to wildland fires. Currently, research is underway across North America to better understand ignition processes associated with flying fire brands and how to protect buildings from them. ${ }^{78}$ Fire tests will likely be needed for determining the performance of building ventilation systems, utility penetration systems, roofing materials, exterior finishes, and window systems.

- Fire measurement technologies are needed that define the ease with which materials ignite. The ignition of materials is an important element associated with fire growth and heat release rate for fires. By controlling the ignitibility of materials, it will have a direct impact on the rate of fire growth associated with the ignition of secondary materials. This reduces the chance of flashover and will directly impact the production of dangerous quantities of carbon monoxide and other toxic fire gases.

- Although controlling rate of heat release for materials has a significant impact on fire toxicity, work is still needed to better control the production of toxic pyrolysis and combustion products. Improvements are needed in fire test methods for

\footnotetext{
${ }^{78}$ Manzello, S. L.; Cleary, T. G.; Shields, J. R.; Yang, J. C., "Urban-Wildland Fires: On the Ignition of Surfaces by Embers," Combustion Institute/Western States, Central States and Eastern States. Fourth (4th) Joint Meeting of the U.S. Sections. Hosted by The Eastern States Section of the Combustion Institute and Drexel University. E3 - Fire research III/Paper E12. March 20-23, 2005, Philadelphia, PA, 1-6 pp, 2005.
} 
toxicity that will allow for more accurate predictions of the toxic affects of fire gases on humans. Control of the pyrolysis and combustion toxicity of materials reduces the threat from one of the major contributors to the death of humans from fire.

- With the move away from the use of oil products for energy production, transportation, and home heating new fire test methods may be needed to address the possibilities of unique fire conditions associated with the proposed alternate fuels (e.g., alcohol, compressed natural gas, and hydrogen) and other new fuels that may be developed.

- Also the move to alternative and renewable energy sources may create new hazards associated with fire in which unique fire test methods are required to quantify the performance of home heating systems that may include items such as fuel cells, advanced photovoltaic systems, and hydrogen based systems.

- Fire test methods may be required for the evaluation of new classes of materials that are based on advancements in materials sciences that possess unique fire properties.

- As humans move from earth to space-bound destinations, new challenges associated with the needs of fire testing have been emerging. Some of the issues already under study include "micro-gravity" combustion processes and combustion processes in atmospheres different than that found on Earth. The first fire tests conducted in space by the United States were done on the Skylab Space Station, in 1974, and work has continued on the Space Shuttle and on the 
International Space Station. ${ }^{79,80}$ Also, as commercial access to space develops materials used in the construction of spacecraft and space habitats (laboratories, hotels, and recreation facilities, etc.) will be required to meet some form of fire safety standards. Additionally, as space exploration continues, the understanding of combustion processes of materials unique to non-terrestrial conditions (e.g. different gravity, different atmospheric pressure, and different gas concentrations) may eventually be required.

\section{A Look into the Distant Future of Fire Testing}

Like all things, the need for fire testing will ultimately come to an end. It will end gracefully as science and engineering develop uniquely crafted materials that will not burn. However, there may still be a need for some materials that have a combustible nature. With these materials the understanding of their properties, which would have come from fire testing, will come through rationalization by the intelligent machines that create the materials. These intelligent machines, when asked, will provide a detailed assessment of how the materials will ignite before they are instantly extinguished by interactions with miniature protective elements within the materials or by other materials that sense combustion and have the capability to independently initiate a fire suppression process. Human interactions associated with the control of unwanted fires will only exist through thought connected communications with the intelligent machines or by verbal discussions with the machines that are hopefully under human control and serving the

\footnotetext{
${ }^{79}$ Kimzey, J. H.: Skylab Experiment M479 Zero Gravity Flammability. Proceedings of the $3^{\text {rd }}$ Space Processing Symposium on Skylab Results. Marshall Space Flight Center, Huntsville, AL, Vol. I June 1974, pp. 115-130. (post flight)

${ }^{80}$ Ross, Howard D. (Editor), "Microgravity Combustion, Fire in Free Fall," Academic Press, New York, 2001.
} 
best of human needs. At this point in time, human life will be radically different. If you really want to conduct a fire test on a material, the intelligent machine will provide live action virtual images of the requested fire test with its time based outcome calculated from accurate physics and chemistry based computer codes. At the end of a hard day of work, the fire in your virtual fire place will be a realistic active holographic simulation that emits radiant energy as it mimics the flicker of the moving flame, and the comforting smell of wood smoke seeping from the fireplace into the room will be generated by the "Highly Articulate Linguistic" intelligent machine, in the burning wood scent that you enjoy the most. As the machine completes its reading of this brief history of fire testing to you, you will throw another virtual log onto the fire, the holograph displays the newly calculated burning behavior as the log ignites and begins to burn, you will lean back in your most comfortable fire-proof furnishing, take a sip of your favorite wine, close your eyes, and dream of the exhilarating "Good Ole Days" of fire testing.

\section{Summary}

As can be seen by the reader, this thesis is an attempt to provide order to the development of science and engineering that support the establishment of fire testing, describe the situations that signaled the needs for fire test method development, and to establish a general historical timeline for the processes that brought fire test methods to their current state of maturity. It has also provided an opportunity to discuss the current needs associated with fire testing and provides opportunities for projecting the concepts of fire testing into the future. The future of fire science and fire testing starts with this 
generation; while, a complete understanding of fire and its behavior in the wide range of environments awaits discovery by future generations.

\section{Acknowledgments}

Appreciation is extended to Kathy Whisner and Regina Burgess of the NIST, BFRL Research Information Service for their assistance in locating reference materials for this document. Randy Laymon of Underwriters Laboratories is also recognized for assisting with historical information for Underwriters Laboratories, Inc. Additionally, Linda Mackay and Stephanie Naoum of the National Fire Protection Association assisted with providing historical information from NFPA. Appreciation is extended to Dr. Rodney Bryant (NIST/BFRL) for assisting with locating reference information on the development of hot-wire anemometry. Appreciation is extended to Dr. Greg Linteris (NIST/BFRL, NASA Astronaut) for his assistance in obtaining information on fire testing in space. Appreciation is also extended to Dr. Anthony Hamins for sharing his views on the future of fire testing.

Note: Contributions by the National Institute of Standards and Technology are not subject to copyright. 




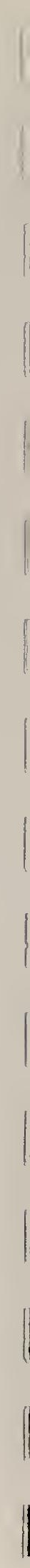

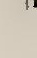

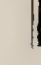

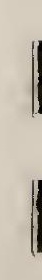

